\title{
The earliest example of sexual dimorphism in bivalves-evidence from the astartid Nicaniella (Lower Jurassic, southern Germany)
}

\author{
Baran Karapunar, ${ }^{1,2}$ (D) Winfried Werner, ${ }^{2,3}$ Franz T. Fürsich, ${ }^{4}$ and Alexander Nützel ${ }^{1,2,3}$ \\ ${ }^{1}$ Ludwig-Maximilians-Universität, Department für Geo- und Umweltwissenschaften, Paläontologie und Geobiologie, Richard- \\ Wagner-Strasse 10, 80333 München, Germany <baran.karapunar@campus.lmu.de> \\ ${ }^{2}$ SNSB-Bayerische Staatssammlung für Paläontologie und Geologie, Richard-Wagner-Strasse 10, 80333 München, Germany <werner@ \\ snsb.de>, <nuetzel@snsb.de> \\ ${ }^{3}$ GeoBioCenterLMU, Richard-Wagner-Strasse 10, 80333 München, Germany \\ ${ }^{4}$ Fachgruppe Paläoumwelt, GeoZentrum Nordbayern der Universität Erlangen-Nürnberg, Loewenichstrasse 28, 91054 Erlangen, Germany \\ $<$ franz.fuersich@fau.de>
}

\begin{abstract}
Protandrous sex change (sex change from male to female) is one of the diverse sexual expressions exhibited by bivalves, but its expression in the shell is quite rare. Previous studies on living and fossil astartids suggest a relationship between protandrous sex change and the formation of crenulations on the ventral shell margin at later ontogenetic stages. Here we report the formation of such crenulations in the Early Jurassic astartid Nicaniella rakoveci (Kuhn, 1935) from the Amaltheenton Formation at Buttenheim, Franconia. This is the earliest known record of protandrous hermaphroditism in fossil bivalves, predating previous reports by at least $13 \mathrm{Myr}$. A principal component analysis of linear size measurements and Fourier shape analysis of the shell outlines revealed that the outline of Nicaniella rakoveci specimens varies from subquadrate to subcircular, but this variation is independent of the presence or absence of crenulations and therefore not associated with sex. Crenulated specimens exhibit a lower height/inflation ratio than non-crenulated ones, suggesting that the protandrous females have more inflated valves than the males. The formation of crenulations was probably related to allocation of resources for reproduction. The most likely function of the crenulations was to increase the internal shell volume in the female stage to accommodate more eggs rather than being an adaptation against predation as often assumed for other bivalves. The formation of crenulations is part of the protandrous life history and probably is controlled by a genetic mechanism that is also responsible for sex change.
\end{abstract}

\section{Introduction}

In the course of a monographic treatment of the Early Jurassic bivalves of the Buttenheim claypit (Pliensbachian, South Germany; Karapunar et al., 2020), we found that the small astartid species Nicaniella rakoveci (Kuhn, 1935) is present with two morphs, one with crenulations on the ventral shell margin and the other one lacking such crenulations. In analogy with some Recent bivalve species, the present contribution tests the hypothesis that these differences reflect sexual dimorphism and possibly sequential hermaphroditism (ontogenetic sex change), as previously proposed for Paleocene (Kauffman and Buddenhagen, 1969) and Middle to Late Jurassic astartids (Gardner and Campbell, 2002). If true, this would be one of very few examples for sexual dimorphism in bivalves, and especially in fossil bivalves.

In Recent bivalves, gonochorism (i.e., individuals of a population having separate sexes) is considered to be the dominant reproductive strategy (Heller, 1993; Breton et al., 2018; Ponder et al., 2020). However, a wide spectrum of hermaphroditism also has been observed in bivalves (Sastry, 1979; Policansky, 1982), and hermaphroditism is the predominant reproductive strategy in some groups (e.g., Pectinidae; Beninger and Le Pennec, 2006, p. 176). There are two main kinds of hermaphroditism seen in bivalves. Simultaneous hermaphrodites (functional hermaphrodites; Coe, 1943) produce eggs and sperm at the same time, either in separate egg- and spermproducing tissues within the same gonad, or in distinct female and male gonads (e.g., Placopecten magellanicus [Gmelin, 1791]; Merrill and Burch, 1960). Sequential hermaphrodites change sex by switching the production of gamete types. In contrast to simultaneous hermaphrodites, sequential hermaphrodites have only one type of gonad tissue at any time, although individuals might exhibit mixed gonads during the transition stage (Fretter and Graham, 1964; Breton et al., 2018). Sequential hermaphrodites may change sex either once in a lifetime (consecutive sexuality) or multiple times. Sex change in sequential hermaphrodites with "consecutive sexuality" can be either from female to male (protogyny) or from male to female (protandry) (Hoagland, 1984). Protandry is more common than protogyny in bivalves (Mackie, 1984). Sequential hermaphrodites with "rhythmical consecutive sexuality" may change sex within the same reproductive season or in the next season (e.g., Ostrea edulis Linnaeus, 1758; Coe, 1943). In "alternative sexuality", individuals exhibit only one sex and may change sex in the next reproductive season or not (e.g., Crassostrea virginica [Gmelin, 1791]; Coe, 1943). 
Sex expression in bivalves is not strictly determined. Rare hermaphroditic individuals may occur in gonochoristic populations (e.g., in Mya arenaria Linnaeus, 1758; Coe and Turner, 1938; Sastry, 1979; Heller, 1993). Conversely, gonochoristic individuals can be found in dominantly hermaphroditic populations (e.g., in Mercenaria mercenaria [Linnaeus, 1758]; Sastry, 1979). In addition, gonochoristic populations can switch to hermaphroditism when mating opportunities decrease (Breton et al., 2018).

Sequential hermaphroditism and simultaneous hermaphroditism are suggested to have evolved in response to different selection pressures. According to the low-density model, simultaneous hermaphroditism is advantageous over gonochorism under some conditions (e.g., low population density, low motility) that do not affect mating chances of hermaphrodites but reduce the mating chance of gonochorists (Ghiselin, 1969). Sequential hermaphroditism has been explained by the size advantage model of Ghiselin (1969), which assumes that reproductive potential differs between sexes and that opposite sexes reproduce more effectively at different ages or sizes. According to this model, protandry is favored by species in which size increase in females increases fecundity, but size increase in males does not affect fecundity significantly. Protogyny in bivalves has been explained by the resource availability model (Breton et al., 2018). According to this model, under conditions of lower resource availability, the reproductive success of females decreases faster than that of males because eggs require more resources per unit to be produced compared to sperm. Although sequential hermaphroditism is considered to be an adaptation to prevent inbreeding or self-fertilization (Ghiselin, 1969), self-fertilization is reported in sequential hermaphrodites (e.g., Montacutona compacta [Gould, 1861]; Morton, 1980), and strategies to avoid self-fertilization (e.g., spawning eggs and sperm at different times or differential ripening of the gametes) are known in simultaneous functional hermaphrodites as well (Fretter and Graham, 1964; Breton et al., 2018).

Previous studies suggested that sex change in bivalves is affected by the environment (e.g., food availability, temperature), and various epigenetic and genetic mechanisms have been proposed to influence sex determination in bivalves (Gosling, 2015; Breton et al., 2018).

Sexual dimorphism is a very rare phenomenon in bivalves and hardly ever expressed in shell morphology, except in a few species. In the protandrous hermaphroditic species Austrodevonia percompressa (Dall, 1899) and Orobitella floridana (Dall, 1899) (family Lasaeidae), females are significantly larger than the parasitic males, which are living attached to the mantle of the female (Jenner and McCrary, 1968; Chanley and Chanley, 1970). In contrast to those of $O$. floridana, the males of A. percompressa do not develop shells. Parasitic dwarf males also occur in gonochoristic and protandrous species of the family Galeommatidae (Gofas, 1991). Dwarf males further occur in the gonochoristic species Zachsia zenkewitschi Bulatoff and Rjabtschikoff, 1933 (Teredinidae) (Turner and Yakovlev, 1983; Shipway et al., 2016), in the protandrous wood-boring species Xylophaga supplicata (Taki and Habe, 1950) (family Xylophagaidae; Haga and Kase, 2013), and in the protandrous cementing bivalve Ostrea puelchana d'Orbigny, 1842 (Pascual et al., 1989).
Sexual dimorphism expressed in shell shape and allometric growth was reported in members of the family Unionidae (Heard, 1975; Kotrla and James, 1987; Avelar et al., 1991; Zieritz and Aldridge, 2011). In the gonochoristic unionids Epioblasma capsaeformis (Lea, 1834) and Epioblasma brevidens (Lea, 1831), the postero-ventral part of the females differs in size and shape due to modifications of the marsupial gills (Mackie, 1984). In a few living carditid species (e.g., Thecalia concamera [Gmelin, 1791], Milneria kelseyi Dall, 1916), the females form a pouch in the shell that serves as marsupium for the larvae (Stanley, 1988; Pérez and Soto, 2021). Differences in shell convexity and ornamentation pattern in some EoceneOligocene alticostate Venericardia species (family Carditidae) and in two Upper Cretaceous morphotypes of Sphenoceramus were interpreted as sexual dimorphism by Heaslip (1969) (see Stanley in Heaslip, 1969, for an alternative view). Differences in valve convexity, inflation, ornamentation, elevation of beaks, strength of cardinals, and depth of muscle scars in Venericardia inaequalis (Philippi, 1887) from the Oligocene-Miocene of Argentina were interpreted as sexual dimorphism by del Río (1995). Pérez et al. (2017) came to a similar conclusion to explain differences in the valve convexity of Darwinicardia patagonica (G.B. Sowerby, 1846). The sexual dimorphism observed in Unionidae and Carditidae is considered to have developed as a consequence of brooding in females.

The presence of sexual dimorphism in living and fossil members of the family Astartidae has been suggested previously (Kauffman and Buddenhagen, 1969; Gardner and Campbell, 2002). Some of the living members of Astarte are protandrous hermaphrodites (e.g., Astarte sulcata [da Costa, 1778]). In these protandrous species, all young individuals are males, but not all change into females in later stages (Saleuddin, 1964, 1965). In most of the living species of Astarte, individuals occur with and without crenulations along the commissural shell margin, as is also the case in the Jurassic species studied herein. Some Astarte species have no crenulations at all, but no species are known to comprise only crenulated individuals. In the protandrous species, large individuals are dominantly crenulated, but all small individuals have smooth shell margins. Similarly, most of the large individuals are female (Kauffman and Buddenhagen, 1969). This observation led Ostroumoff (1900) to postulate a link between the presence of crenulations and the sex of an individual in the protandrous hermaphroditic species Astarte sulcata. Spärck (1927) tested this hypothesis with a small sample consisting of 32 specimens and showed that crenulated margins are found in adult males as well as in females, but all non-crenulated individuals are males. Consequently, he suggested that sexual dimorphism is not correlated with the presence or absence of crenulations. Kauffman and Buddenhagen (1969) reported the presence of marginal crenulations in larger specimens in populations of Astarte marylandica Clark, 1895 from the Paleocene Aquia Formation of Maryland, USA, in addition to changes in other morphological characters (i.e., relative shell convexity and height, umbonal swelling, shell thickness, development of concentric rugae), and suggested the presence of protandry in Astarte marylandica. Gardner and Campbell (2002) reported variations in morphological traits in Middle to Late Jurassic (Bajocian-Kimmeridgian; 170-152 Myr) astartids. They demonstrated that in Notoastarte 
variabilis Gardner and Campbell, 2002, crenulated shells dominate the larger size cohorts and are thicker and more inflated than non-crenulated ones. They interpreted these variations as protandrous hermaphroditism. They also described Nicaniella notipelagos Gardner and Campbell, 2002, based on four specimens with different shell outlines and ornaments, and included one crenulated and one non-crenulated individual.

Here, we report shell dimorphism (i.e., the formation of crenulations at the inner shell margin during later ontogenetic stages) within the Early Jurassic (Pliensbachian, Spinatum Zone; $183 \mathrm{Myr}$ ) astartid bivalve Nicaniella rakoveci, and discuss this phenomenon in the context of protandrous hermaphroditism as it is known from Recent hermaphrodite members of the family Astartidae.

\section{Materials and methods}

The upper Pliensbachian (Lower Jurassic) Amaltheenton Formation at Buttenheim, Franconia, southern Germany, yields a diverse invertebrate fauna, of which bivalves are the most diverse macrobenthic component (Karapunar et al., 2020). Two species of Nicaniella are present, both of which include individuals with crenulated and non-crenulated shell margins: Nicaniella rakoveci (Kuhn, 1935) and Nicaniella schoberti Karapunar et al., 2020 (Fig. 1). The two species clearly differ from each other in morphological parameters and ornamentation. Nicaniella schoberti is a very small species (up to $2 \mathrm{~mm}$ in height) and rarer than $N$. rakoveci. Therefore, $N$. schoberti is more difficult to analyze with regard to potential sexual

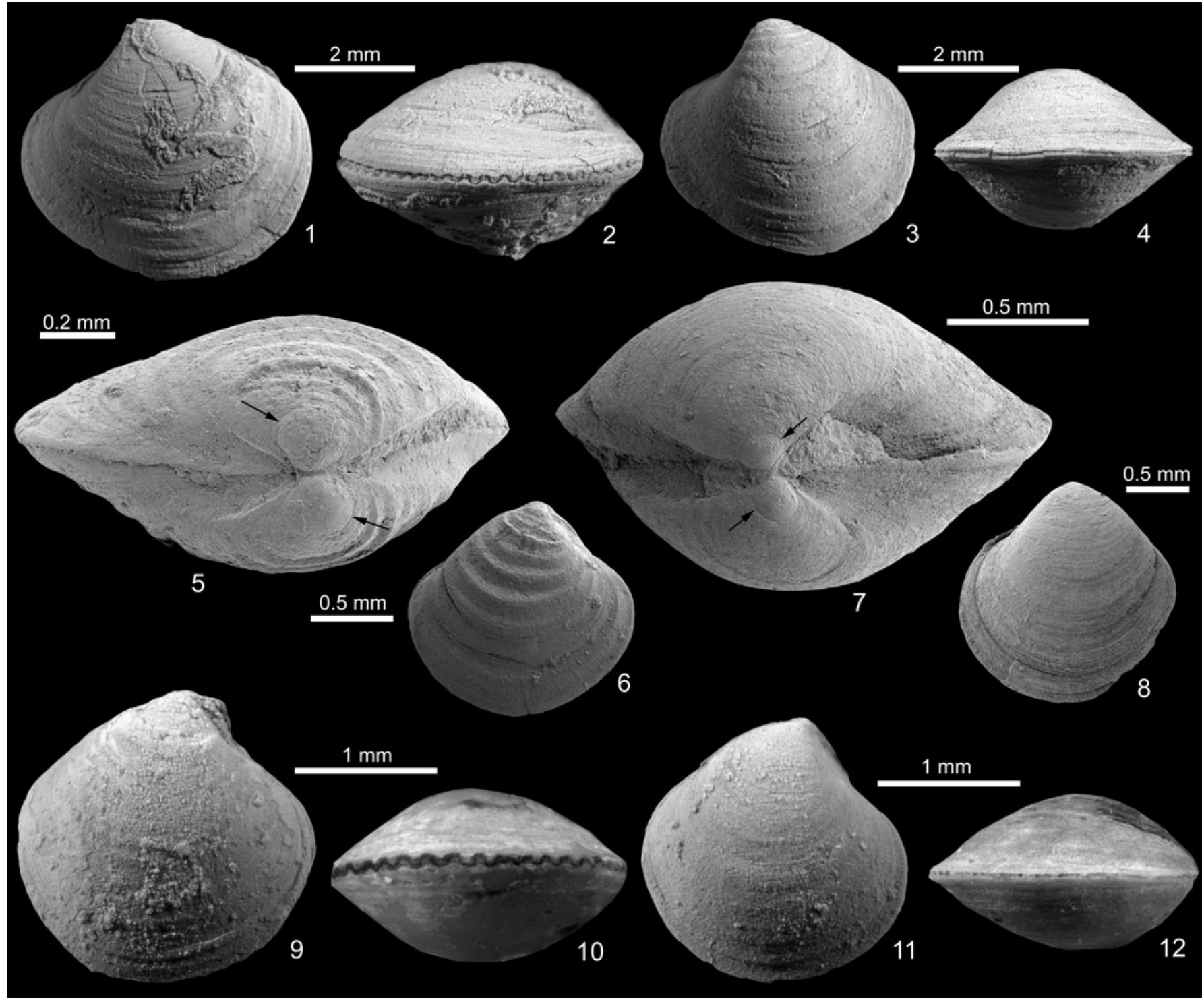

Figure 1. Sexually dimorphic shells of Nicaniella from the Pliensbachian Amaltheenton Formation of Buttenheim. (1-6) Nicaniella rakoveci (Kuhn, 1935): (1, 2) specimen with crenulated ventral margin, SNSB-BSPG 2011 XI 719; $(\mathbf{3 , 4})$ specimen with smooth ventral margin, SNSB-BSPG 2011 XI 718; (5, 6) SEM image of a juvenile specimen with preserved prodissoconch, arrows indicating the prodissoconch-dissoconch boundary, SNSB-BSPG 2011 XI 331; (7-12) Nicaniella schoberti Karapunar et al., 2020: (7, 8) SEM image of a specimen with preserved prodissoconch, arrows indicating the prodissoconch-dissoconch boundary, SNSB-BSPG 2011 XI 329; (9, 10) specimen with crenulated ventral margin, SNSB-BSPG 2011 XI 746; (11, 12) specimen with smooth ventral margin, SNSB-BSPG 2011 XI 744. 

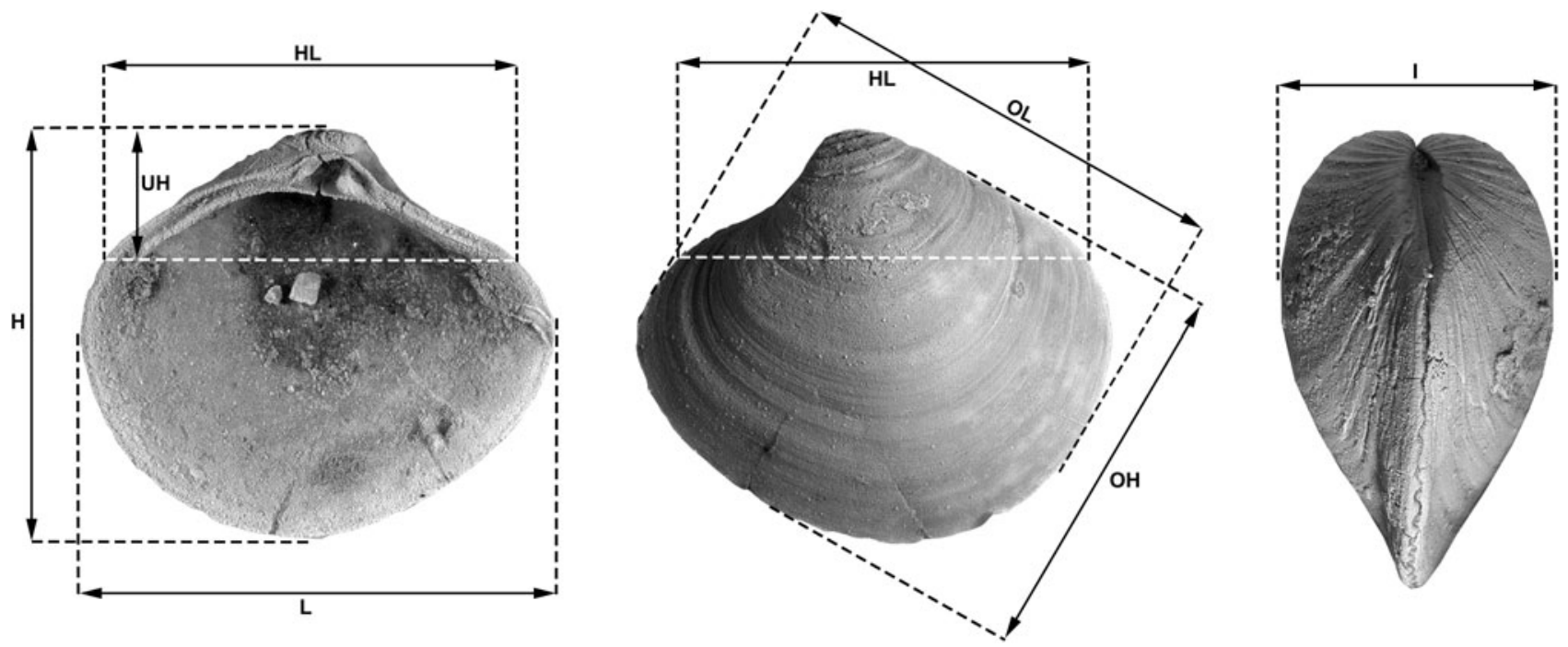

Figure 2. Linear measurements used in this study; $\mathrm{H}=$ height, $\mathrm{HL}=$ hinge length, $\mathrm{I}=$ inflation, $\mathrm{L}=$ length, $\mathrm{OH}=\mathrm{oblique}$ height, $\mathrm{OL}=\mathrm{oblique}$ length, $\mathrm{UH}=\mathrm{umbo}$ height.

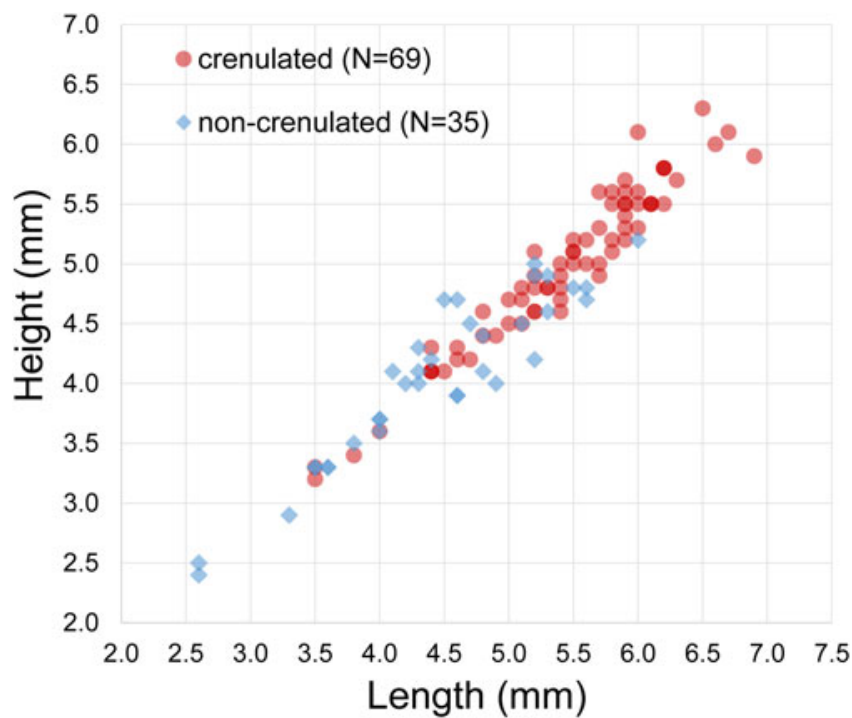

Figure 3. Scatter plot of height vs. length of Nicaniella rakoveci specimens.

dimorphism, and the present study focuses on Nicaniella rakoveci.

Nicaniella rakoveci is one of the most abundant infaunal bivalve species from the Amaltheenton Formation of Buttenheim. There are 545 specimens (119 non-crenulated, 426 crenulated) out of $\sim 7000$ studied bivalve specimens of the collection from Buttenheim (Karapunar et al., 2020). Most of the specimens are crushed or fragmentary, and therefore not suitable for morphometric analysis. Consequently, 104 relatively wellpreserved specimens (35 crenulated, 69 non-crenulated) were selected for morphometric analyses. Their height, length, and inflation were measured with a digital caliper (Fig. 2, Appendix S1). Figures 3, 4, 6, and 7 are based on these caliper measurements. The left valves of 57 specimens were photographed with a microscope camera Leica DMC 450 for Fourier shape analysis and additional linear measurements (Fig. 2, Appendix

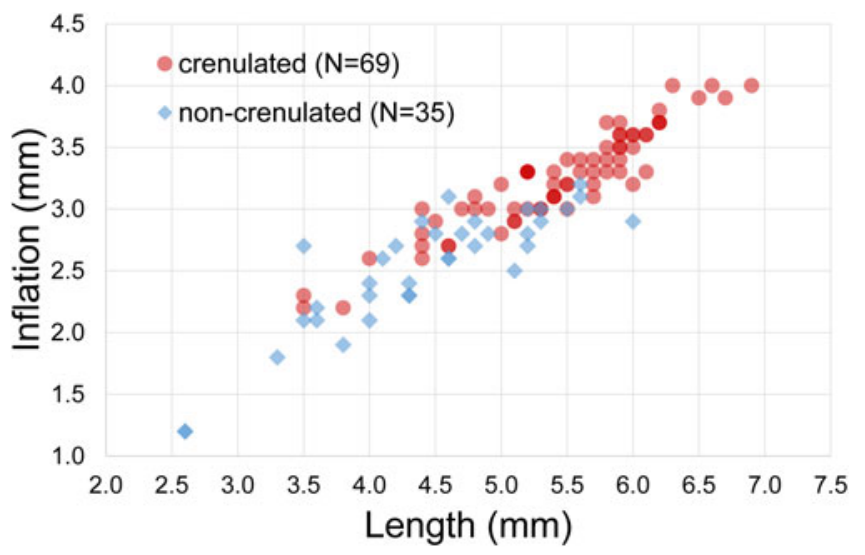

Figure 4. Scatter plot of inflation vs. length of Nicaniella rakoveci specimens.

S2). Linear measurements of the 57 specimens were taken from the photographs and subsequently subjected to Principal Component Analysis (PCA) in PAST (Hammer et al., 2001). Figure 5 shows a PCA plot based on measurements taken from the photographs.

The shell outline of Nicaniella rakoveci is variable among the individuals and ranges from subcircular to obliquesubrectangular. In order to assess various potential directions of allometric growth, oblique height and oblique length were measured and analyzed in addition to height and length (Fig. 2). It has been suggested that the height and swelling of the umbo differ between sexes within the same astartid species (e.g., Kauffman and Buddenhagen, 1969), as well as interspecifically (e.g., Gardner and Campbell, 2002). In this context, the height of the umbo was measured as the distance between the dorsal tip of the umbo and the line connecting the anterior and posterior ends of the hinge. Because the specimens studied herein are articulated, the end points of the hinge were interpreted from the external valve morphology. The antero-dorsal and postero-dorsal hinge margins are relatively straight and 


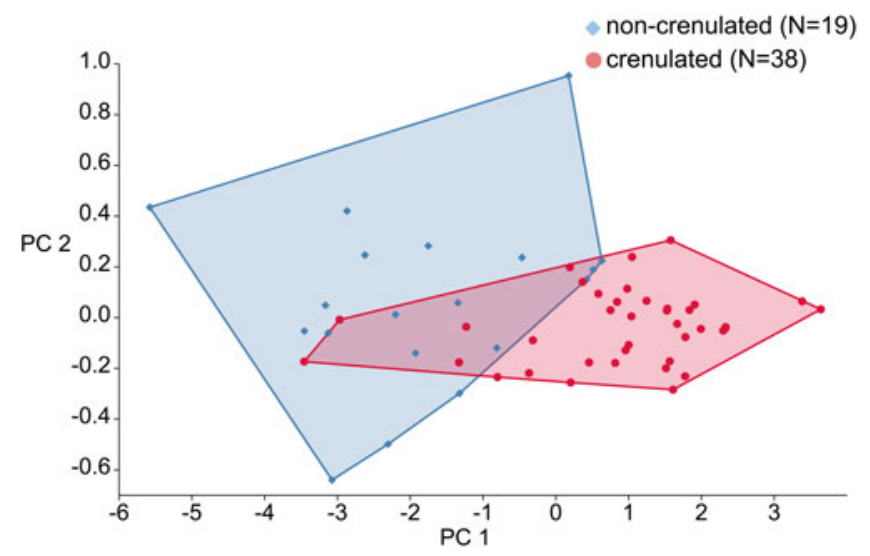

Figure 5. Scatter plot of PC 2 vs. PC 1, obtained from PCA of the linear measurements of Nicaniella rakoveci specimens. PC 1 explains $96.9 \%$ of the variance and PC 2 explains $1.4 \%$ of the variance in the linear measurement dataset.

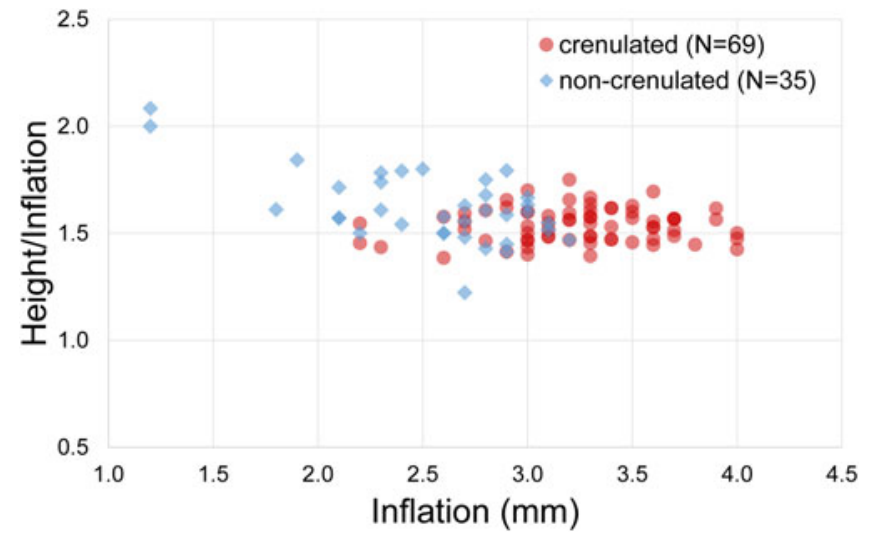

Figure 6. Scatter plot of height/inflation ratio vs. inflation of Nicaniella rakoveci specimens.

pass smoothly into the convex anterior and posterior margins. The ends of the relatively straight margins were regarded as the end-points of the hinge (Fig. 2).

Nicaniella rakoveci is an equivalved species. Fourier shape analysis was conducted on the left valves only. Fourier shape analysis decomposes an outline into the sum of harmonically related trigonometric functions. Each function (harmonic) has two independent Fourier coefficients—one represents the amplitude and the other one represents the phase angle (angular offset relative to the starting position) (Haines and Crampton, 2000). The two coefficients are independent variables that determine the shape of the outline and are evaluated by using PCA. For Fourier shape analysis, the programs Hangle, Hmatch, and Hcurve were used (Haines and Crampton, 2000; Schneider et al., 2010; Hethke et al., 2018). First, the outlines were transformed into 1000-2000 Cartesian coordinates using the program tpsDig2 (Rohlf, 2017). The Cartesian coordinates of the outlines were then transformed into harmonically related sine and cosine curves by Hangle, which performs Fast Fourier Transform (Haines and Crampton, 2000). The first 12 harmonics were selected to reconstruct the outline of the left valves (for the coefficients of harmonics, see Appendix S3). The results obtained from Hangle were adjusted by Hmatch, which matches the shapes of the outlines and standardizes the starting point for

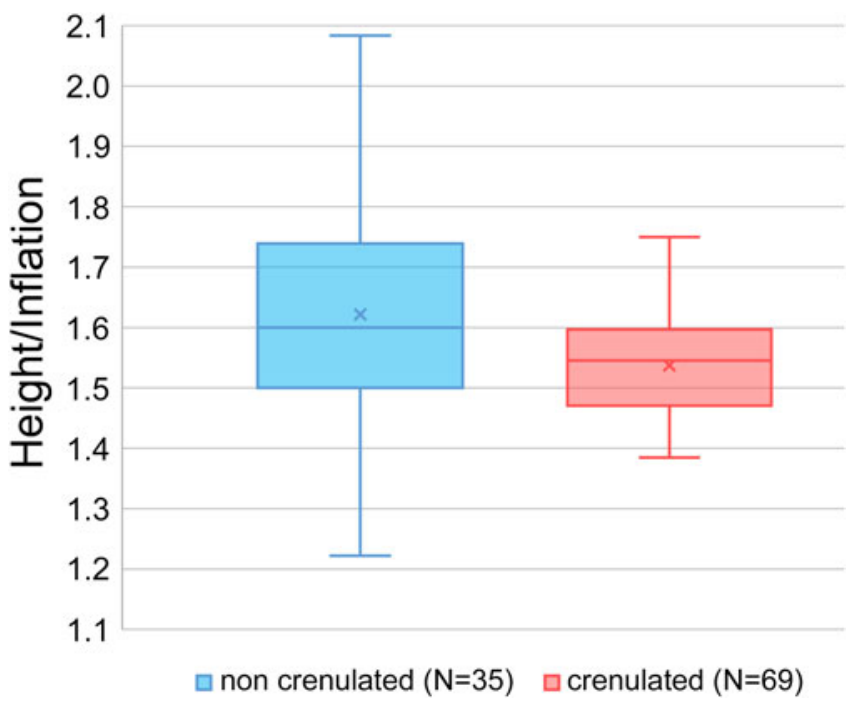

Figure 7. Box plots showing the distribution of height/inflation ratio among non-crenulated (left) and crenulated (right) specimens. The horizontal line within the box represents the median, $x$ represents the mean, the box represents the central $50 \%$ of the data, and the whiskers represent the observed range. The difference in the $\mathrm{H} / \mathrm{I}$ frequency distribution between crenulated and non-crenulated individuals is statistically significant (Kolmogorov-Smirnov, $\mathrm{D}=0.29, \mathrm{p}<0.05$ ).

the Fourier analysis. Hcurve is employed to produce outlines based on the harmonics produced by Hmatch. Fourier shape analysis was used previously to evaluate intraspecific and interspecific variation in shell outlines of different groups of fossil bivalves (Schneider et al., 2010, 2011; Zieritz and Aldridge, 2011).

Repository and institutional abbreviation.-All specimens used in this study are housed in the Bayerische Staatssammlung für Paläontologie und Geologie (SNSB-BSPG), Munich.

\section{Results}

Linear measurements. - Smooth margins are only present in specimens shorter than $6 \mathrm{~mm}$, and individuals with crenulated margins dominate the larger size fractions (Figs. 3, 4). Crenulated specimens are more frequent than non-crenulated specimens above the height of $4.5 \mathrm{~mm}$ and length of $4 \mathrm{~mm}$. Specimens shorter than $4.5 \mathrm{~mm}$ or lower than $4 \mathrm{~mm}$ are regarded as small. Variation in the size ratios $\mathrm{H} / \mathrm{L}, \mathrm{OH} / \mathrm{OL}$, and $\mathrm{UH} / \mathrm{H}$ does not significantly differ between crenulated and non-crenulated individuals. PC 1 and PC 2 explain $96.9 \%$ and $1.4 \%$ of the variation in the linear measurement dataset, respectively. All size variables $(\mathrm{H}, \mathrm{L}, \mathrm{I}, \mathrm{UH}, \mathrm{HL}, \mathrm{OH}, \mathrm{OL})$ have positive loadings on PC 1 (Appendix S4), therefore PC 1 is interpreted as size-related (Fig. 5). The most significant loadings on PC 2 are inflation (negative) and $\mathrm{H} / \mathrm{I}$ ratio (positive). PC 2 indicates that the maximum variance between the two groups is caused by inflation. The $\mathrm{H} / \mathrm{I}$ value is higher in non-crenulated individuals (Figs. 6, 7; note the similarity of Fig. 6 to Fig. 5). The difference in the H/I frequency distribution between crenulated and non-crenulated individuals is statistically significant (Kolmogorov-Smirnov, D = 0.29, $\mathrm{p}<0.05$ ).

Fourier shape analysis.-Fourier shape analysis of the shell outlines has been evaluated with PCA (Fig. 8), which suggests 


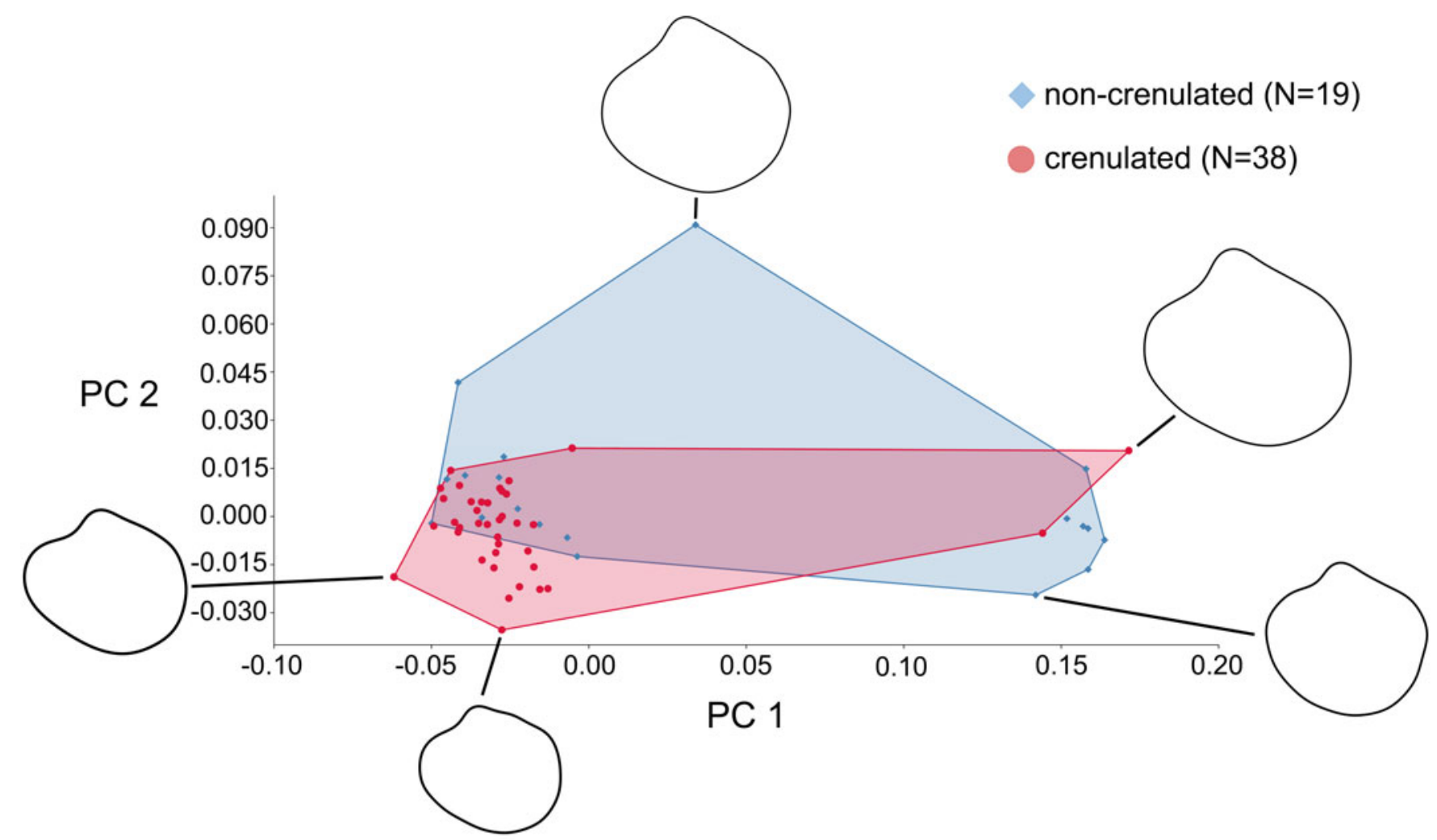

Figure 8. Scatter plot of PC 2 vs. PC 1, obtained from PCA of the Fourier shape coefficients; outlines of five Nicaniella rakoveci specimens are displayed. PC 1 explains $73.3 \%$ and PC 2 explains $6.1 \%$ of the shape variance.

no significant shape difference between crenulated and non-crenulated individuals. PC 1 explains $73.3 \%$ of the shape variance and depicts whether the outline is more angular (subquadrate) or more rounded (subcircular to subovate). The specimens form two distinct clusters on the PC 1 axis, which can be distinguished by the relative shape of the specimens. The specimens with a PC 1 value around 0.15 have a slightly concave postero-dorsal margin, which forms a rounded corner when meeting with the posterior margin, and they have a more acutely rounded ventral margin. The specimens with negative PC 1 values, which form the second, larger cluster, have a convex postero-dorsal margin and well-rounded shell margins. These two clusters are formed independent of the presence/ absence of crenulations, therefore they are not sex-related, and are regarded as two shape variants of a single species. PC 2 explains $6.1 \%$ of the shape variance and depicts the degree of protrusion of the umbo from the dorsal shell margin, which corresponds to the linear measurement "umbo height." The specimens do not form distinct clusters on the PC 2 ( umbo height) axis, suggesting that the range of variation of umbo height is similar among the crenulated and non-crenulated specimens.

\section{Discussion}

Sexual dimorphism in Nicaniella rakoveci.-The Nicaniella rakoveci collection from Buttenheim, containing the 545 specimens investigated, is composed of individuals with crenulated and non-crenulated shell margins. Non-crenulated specimens dominate by far the small size fraction (shorter than $4.5 \mathrm{~mm}$ and lower than $4 \mathrm{~mm}$ ), whereas the percentage of crenulated specimens increases with increasing shell size (Figs. 3, 4). At first glance, this would seem to point to the coexistence of two closely related, but separate species. However, as already discussed by Karapunar et al. (2020), the crenulated and non-crenulated individuals are considered conspecific based on general shell morphology and ornamentation. This is now corroborated by the PCA of the linear measurements and the Fourier shape analysis, which both suggest that the crenulated and non-crenulated specimens do not differ significantly in size ratios and shell outline shape. The only distinct difference is a lower height/ inflation ratio of the crenulated specimens. This can be explained by two morphologically different ontogenetic stages. During the first stage without crenulations (see below), height increased faster than inflation. The downshift of the arithmetic mean and the median height/inflation value (Figs. 6, 7) can be correlated with formation of the crenulations, during which the shell margin thickened, and thus the inflation increased.

The presence/absence of crenulations at the ventral margin of $N$. rakoveci can be best interpreted as expression of a consecutive shell dimorphism, as is known or suggested, respectively, for many Recent and some fossil astartids (Kauffman and Buddenhagen, 1969; Gardner and Campbell, 2002). The possibility that the non-crenulated and the crenulated specimens come from 
different horizons, and thus reflect adaptations to different environmental conditions, is very unlikely because the sediments within the Amaltheenton Formation at Buttenheim that yielded the studied specimens are very uniform in lithology and faunal content. The fact that only $28 \%$ of the 545 studied specimens are non-crenulated may be partly explained by the generally smaller size of specimens with smooth margins. The low proportion of specimens with smooth margins might be due to overlooking very small specimens when picking fossils in the field from the surface (sampling bias). Nevertheless, the percentage of non-crenulated individuals of the studied collection from Buttenheim is close to that reported for Astarte marylandica Clark, 1895 from the Paleocene of Maryland (33\%, Kauffman and Buddenhagen, 1969). The presence/absence of crenulations in the latter species was interpreted by these authors as protandrous sexual dimorphism, a hypothesis that is adopted here also for $N$. rakoveci.

Life stages of protandrous astartids.-Extant Astarte sulcata embryos are direct developers without a swimming larval phase (Saleuddin, 1964). This is also the case in extant Astarte castanea, which releases eggs in an adhesive capsule and disperses them only for a few centimeters (Goodsell et al., 1983). Nicaniella rakoveci has a smooth prodissoconch, $0.2 \mathrm{~mm}$ in width and without a distinct transition from prodissoconch I to prodissoconch II (Fig. 1.5), which might indicate a direct development (Jablonski and Lutz, 1980). However, Koppka and Malchus (2007) reported that prodissoconch I and II stages are distinguishable in other species of Nicaniella.

Spärck (1927) showed that the crenulations in Astarte sulcata do not form simultaneously with sex change. However, this does not mean that the crenulations are an ontogenetic feature that is unrelated to sex change. If the crenulations were simply an ontogenetic feature, then one would expect all large adults in populations of Recent Astarte sulcata to exhibit crenulated shell margins (Kauffman and Buddenhagen, 1969). However, all individuals with smooth margins (both juveniles and adults) exhibit male gonads (Spärck, 1927; Kauffman and Buddenhagen, 1969). According to Kauffman and Buddenhagen (1969), crenulations start to appear at a life stage similar to that at which the sex change occurs in Astarte sulcata populations, and the percentage of crenulated individuals is the same as that of females. It seems that the formation of crenulations is a morphological expression of a particular developmental stage in the protandrous life history of at least some astartids. According to previous observations (Spärck, 1927; Saleuddin 1964, 1965; Kauffman and Buddenhagen, 1969), the life history of Astarte sulcata can be divided into three consecutive stages, but the timing of the transitions between the stages might vary among individuals. In the first stage, individuals of $A$. sulcata invest all energy in fast body growth and possess no crenulations. In this stage, all individuals are males with immature gonads. In the second stage (or mid-adult stage), individuals have mature male gonads and produce sperm. Near the end of the second stage, spermatocytes disintegrate, oocytes begin to form (Saleuddin, 1964), and crenulations appear. In the third stage (late-adult stage), individuals completed sex change from male to female, produce eggs, and continue to possess crenulations.
Apart from the crenulations, the presence of growth rugae in later ontogenetic stages is interpreted as a shell expression of sex change in protandrous species (e.g., Astarte marylandica; Kauffman and Buddenhagen, 1969). Nicaniella rakoveci develops commarginal ribs during the early life stage, and the valve surface becomes smooth in later stages. However, this change in ornamentation pattern occurs before development of the crenulations and is, thus, apparently not correlated with sex change. The crenulations and differences in shell inflation seem to be the only characters that can be attributed to shell dimorphism in Nicaniella rakoveci in the context of a protandrous life style.

Obviously, sex change in astartids is associated with the formation of crenulations and the development of crenulations is not an independent ontogenetic process. This may explain why individuals that have changed their sex are present only among individuals with crenulated margins and absent in individuals with smooth margins in Recent Astarte sulcata populations. Large individuals with smooth margins and mature male gonads in Recent populations are the individuals that remained in the second stage and could not pass to the third stage. As a result, the sex changing mechanism in these individuals was not activated and crenulations are not formed. It can be assumed that the genes involved in sex change in Recent astartids were also present in the late Pliensbachian astartids, ca. $183 \mathrm{Myr}$ ago. Activation of the genetic mechanism seems to slow down growth and cause the formation of crenulations, gonad maturation, and sex change.

The function of crenulations. - Crenulations at the shell margin are usually regarded as an adaptation against predators by enabling tight closure of the valves (e.g., Alexander and Dietl, 2003; Vermeij, 2013). However, the crenulations in the discussed astartids are restricted to a fraction of the adult specimens, which are here interpreted as protandrous females; therefore, crenulations are regarded as an adaptive trait related to sex change rather than to extrinsic factors such as predation pressure. The functional adaptation of crenulations in protandrous astartids could not be explained previously (Kauffman and Buddenhagen, 1969, p. 92). Here, we interpret the function of crenulations as increasing inflation. The main advantage of the crenulations in $N$. rakoveci was an increase of the internal shell volume without changing the direction of shell growth or valve expansion rate. The ratio of inflation to height of a bivalve shell can be increased by decreasing the whorl expansion rate during growth or by changing the direction of growth (Vermeij, 2002). If inflation is increased by changing the growth direction, the height and swelling of the umbo differ between sexes. The change in growth direction is not evident in $N$. rakoveci and the crenulations seem to be responsible for increase in inflation rate. Change in growth direction probably occurred in A. marylandica, as suggested by the umbonal swelling reported by Kauffman and Buddenhagen (1969). Crenulations are a series of protrusions directed to the opposite valve (Fig. 1.2, 1.10), thickening shell margins and thus providing increase in the inflation of a shell as much as the height of a crenulation. Increase in inflation and internal shell volume provides more space for accommodating eggs in protandrous females (Kauffman and Buddenhagen, 1969). The formation of crenulations is probably related to change in 
resource allocation and demarks the transition from the stage of investing energy in body growth to the stage of investing in reproduction. Dall's (1903) report that the crenulations were formed during resting periods when the growth rate decreased supports the resource allocation argument.

Shell dimorphism in fossil bivalves. - Shell dimorphism in the geological past has been reported from several bivalve families (e.g., Inoceramidae: Heaslip, 1969; Astartidae: Kauffman and Buddenhagen, 1969; Gardner and Campbell, 2002; Unionidae: Kotrla and James, 1987; Avelar et al., 1991; Carditidae: Stanley, 1988; del Río, 1995). Most of these records are from the Cretaceous or Paleogene/Neogene periods. Up until the present, the oldest records document protandrous hermaphroditism in astartids from the Middle to Late Jurassic (BajocianKimmeridgian) of New Zealand and New Caledonia (Gardner and Campbell, 2002). The case of the astartids Nicaniella rakoveci and Nicaniella schoberti presented here extends the expression of protandrous hermaphroditism in the shell to the Early Jurassic. The genus Nicaniella is known from deposits as early as the Late Triassic to earliest Jurassic (Damborenea and Manceñido, 2012; Ros-Franch et al., 2014), but the presence/ absence of shell dimorphism in Nicaniella species older than Pliensbachian needs confirmation because both gonochorism and hermaphroditism are known to occur in different species within the same astartid genus (e.g., Astarte).

As mentioned previously, protandrous hermaphroditism is explained by the size advantage model of Ghiselin (1969), which assumes that size increase in females increases their fecundity, whereas size increase in males does not affect fecundity significantly. Although Nicaniella rakoveci has a prodissoconch of $0.2 \mathrm{~mm}$ (Fig. 1.5) and reaches a size of up to $7 \mathrm{~mm}$, Nicaniella schoberti, the second, smaller species of Nicaniella at Buttenheim, has a prodissoconch of $0.15 \mathrm{~mm}$ (Fig. 1.7) and only reaches a size of up to $2 \mathrm{~mm}$. Both species are interpreted as direct developers (see above), hence the prodissoconch size may indicate egg size, and the ratio between protoconch size and shell size may indicate potential fecundity, which consequently is lower in Nicaniella schoberti. Although the small size of Nicaniella schoberti does not argue against the size advantage model, it is remarkable that a Nicaniella species stays that small considering that size seems to relate to successful reproduction. This suggests that other factors might have prevailed over reproductive success in the evolution of Nicaniella schoberti, which is known only from the Amaltheenton Formation at Buttenheim and is the smallest bivalve species at that location. Several bivalve species attain a lower maximum size at Buttenheim than at other locations (Fürsich et al., 2020; Karapunar et al., 2020). This reduced size was interpreted as stunting, and the fine-grained substrate and lowered oxygen conditions were considered responsible for this phenomenon (Fürsich et al., 2020; Karapunar et al., 2020). The other bivalve species that has been reported only from the Amaltheenton Formation is the infaunal Rollieria franconica Karapunar et al., 2020. This species is smaller compared to the other, geographically more widely distributed Rollieria species that is present in Buttenheim. Apart from being a possible adaptation to the environmental conditions (soft bottom and low oxygen) that prevailed in the Amaltheenton environment, the small size of these two bivalve species might indicate a shorter lifespan with the advantage of reaching reproductive capability faster and shortening generation time.

The detection of hermaphroditism in fossil bivalve taxa has multifaceted implications (e.g., on systematics, diversity, and understanding the evolution of hermaphroditism). For example, the Early Jurassic Astarte integra Münster in Goldfuss (1837, p. 191, pl. 134, fig. 11) differs from the coeval Astarte voltzii Goldfuss, 1837 (Goldfuss, 1837, p. 190, pl. 134, fig. 8) by its smooth margin and smaller size. Both species were found at the same locality, although not in the same formation. Astarte integra Münster might represent the male stage of Astarte voltzii Goldfuss. A revision of astartid species is needed to clarify such systematic problems. It is unclear whether hermaphroditism is an ancestral or derived character in bivalves (Fretter and Graham, 1964). In most bivalves it is impossible to infer hermaphroditism from their hard parts, but astartids might be an exception. Further studies on living Astarte may clarify the relationship between shell dimorphism and hermaphroditism in greater detail, and additional studies on fossil astartids may show whether hermaphroditism in the family is ancestral or derived.

\section{Conclusions}

In the astartid bivalve species Nicaniella rakoveci from the Pliensbachian of Southern Germany, specimens occur with and without crenulations at the ventral margin. Specimens without crenulations dominate the lower size ranges, those with crenulations dominate the upper (adult) size ranges. In analogy with observations from some Recent and fossil astartids, this phenomenon is interpreted as sexual dimorphism-more precisely as the expression of protandrous hermaphroditism, involving ontogenetic sex change from male (without crenulations) to female (with crenulations). The formation of crenulations in the female stage is linked to a greater inflation of the shell resulting in an increase of the internal shell volume, which is regarded as advantageous for the accommodation of more eggs. Whereas sexual dimorphism is generally very rarely expressed in bivalve shells, this study presents the oldest case of sexual dimorphism in bivalves and shows that the genetic mechanisms of protandrous hermaphroditism known from Recent astartids existed as early as in the Early Jurassic.

\section{Acknowledgments}

M. Hethke (Freie Universität Berlin) is greatly acknowledged for her advice on statistical methods and for introducing BK to Fourier shape analysis. J. Schobert (Hirschaid) is thanked for collecting the specimens and donating them to the BSPG. Reviewers E. Harper and S. Schneider and the associate editor M. Hautmann are acknowledged for their critical comments on the manuscript, which considerably improved the article. Finally, we would like to thank the editors B. Hunda and J. Jin for stylistic improvements. Open access funding enabled and organized by DFG.

\section{Data availability statement}

Data available from the Dryad Digital Repository: https://doi. org/10.5061/dryad.r4xgxd2cg. 


\section{References}

Alexander, R.R., and Dietl, G.P., 2003, The fossil record of shell-breaking predation on marine bivalves and gastropods, in Kelley, P.H., Kowalewski, M., and Hansen, T., eds., Predator-Prey Interactions in the Fossil Record. Topics in Geobiology, v. 20: Boston, Springer, p. 141-176.

Avelar, W.E.P., da Silva Costa, A., Colusso, A.J., and Dal Bo, C.M.R., 1991, Sexual dimorphism in Castalia undosa undosa Martens, 1827. (Bivalvia: Hyriidae): Veliger, v. 34, p. 229-231.

Beninger, P., and Le Pennec, M., 2006, Structure and function in scallops, in Shumway, S.E., and Parsons, J., eds., Scallops: Biology, Ecology and Aquaculture (2nd ed.): Amsterdam, Elsevier Science Publishers, p. 123-227.

Breton, S., Capt, C., Guerra, D., and Stewart, D., 2018, Sex-determining mechanisms in bivalves, in Leonard, J.L., ed., Transitions Between Sexual Systems: Understanding the Mechanisms of, and Pathways Between, Dioecy, Hermaphroditism and Other Sexual Systems: Cham, Switzerland, Springer International Publishing, p. 165-192.

Bulatoff, G.A., and Rjabtschikoff, P.I., 1933, Eine neue Gattung aus der Familie der Teredinidae aus dem Japanischen Meer: Zoologischer Anzeiger, v. 104, p. $165-176$

Chanley, P., and Chanley, M.H., 1970, Larval development of the commensal clam, Montacuta percompressa Dall: Journal of Molluscan Studies, v. 39 p. 59-67.

Clark, W.B., 1895, Contributions to the Eocene fauna of the middle Atlantic slope: Johns Hopkins Circular, v. 15, p. 3-6.

Coe, W.R., 1943, Sexual differentiation in mollusks. I. Pelecypods: The Quarterly Review of Biology, v. 18, p. 154-164.

Coe, W.R., and Turner, H.J., Jr., 1938, Development of the gonads and gametes in the soft-shell clam (Mya arenaria): Journal of Morphology, v. 62, p. 91-111.

da Costa, E.M., 1778, Historia Naturalis Testaceorum Britanniae, or the British Conchology, containing the descriptions and other particulars of natural history of the shells of Great Britain and Ireland: London, Millan, White, Elmsley, and Robson, $254 \mathrm{p}$.

Dall, W.H., 1899, Synopsis of the recent and Tertiary Leptonacea of North America and the West Indies: Proceedings of the United States National Museum, v. 21, p. 873-897.

Dall, W.H., 1903, Synopsis of the family Astartidae, with a review of the American species: Proceedings of the United States National Museum, v. 26, p. 933-951. https://doi.org/10.5479/si.00963801.26-1342.933.

Dall, W.H., 1916, Diagnoses of new species of marine bivalve mollusks from the northwest coast of America in the collection of the United States National Museum: Proceedings of the United States National Museum, v. 52 , p. 393-417.

Damborenea, S.E., and Manceñido, M.O., 2012, Late Triassic bivalves and brachiopods from southern Mendoza, Argentina: Revue de Paléobiologie Volume Spécial, v. 11, p. 317-344.

del Río, C.J., 1995, Sexual dimorphism in the Tertiary carditid Venericardia inaequalis (Philippi, 1887) (Argentina): Proceedings Anales de la Sociedad Científica Argentina 1995, v. 225, p. 103-112.

d'Orbigny, A., 1842, Voyage dans l'Amerique Meridionale, Paléontologie, v. 3, no. 4: Paris, P. Bertrand, $162 \mathrm{p}$.

Fretter, V., and Graham, A., 1964, Reproduction, in Wilbur, K.M., and Yonge, C.M., eds., Physiology of Mollusca, Volume 1: New York, Academic Press, p. $127-164$.

Fürsich, F.T., Karapunar, B., Werner, W., and Nützel, A., 2020, Ecology of the Early Jurassic bivalve Harpax spinosus (J. Sowerby, 1819): Neues Jahrbuch für Geologie und Paläontologie-Abhandlungen, v. 297, p. 227-243.

Gardner, R.N., and Campbell, H.J., 2002, Middle to Late Jurassic bivalves of the subfamily Astartinae from New Zealand and New Caledonia: New Zealand Journal of Geology and Geophysics, v. 45, p. 1-51.

Ghiselin, M.T., 1969, The evolution of hermaphroditism among animals: The Quarterly Review of Biology, v. 44, p. 189-208.

Gmelin, J.F., 1791, Caroli a Linnaei systema naturae per regna tria naturae, ed. 13: Lipsiae [Leipzig], G.E. Beer, v. 1, no. 6, p. 3021-3910.

Gofas, S., 1991, The family Galeommatidae (Bivalvia: Leptonacea) in the eastern Atlantic: Veliger, v. 34, p. 344-353.

Goldfuss, G.A., 1833-1841, Petrefacta Germaniae: Düsseldorf, Arnz, 128 p.

Goodsell, J.G., Lutz, R.A., Castagna, M., and Kraeuter, J., 1983, Nonplanktotrophic larval development of two species of continental shelf bivalves: Journal of Shellfish Research, v. 3, p. 91.

Gosling, E., 2015, Marine Bivalve Molluscs, $2^{\text {nd }}$ ed.: Sussux, UK, Wiley Blackwell, $524 \mathrm{p}$.

Gould, A.A., 1861, Description of new shells collected by the United States North Pacific Exploring Expedition: Proceedings of the Boston Society of Natural History, v. 8, p. 14-32.

Haga, T., and Kase, T., 2013, Progenetic dwarf males in the deep-sea woodboring genus Xylophaga (Bivalvia: Pholadoidea): Journal of Molluscan Studies, v. 79, p. 90-94.
Haines, A.J., and Crampton, J.S., 2000, Improvements to the method of Fourier shape analysis as applied in morphometric studies: Palaeontology, v. 43, p. 765-783.

Hammer, Ø., Harper, D.A., and Ryan, P.D., 2001, PAST: paleontological statistics software package for education and data analysis: Palaeontologia electronica, v. 4, no. 1, p. 9. http://palaeo-electronica.org/2001_1/past/issue1_01.htm.

Heard, W., 1975, Sexuality and other aspects of reproduction in Anodonta (Pelecypoda: Unionidae): Malacologia, v. 15, p. 81-103.

Heaslip, W.G., 1969, Sexual dimorphism in bivalves, in Westermann, G.E.G., ed., Sexual dimorphism in fossil metazoa and taxonomic implications: Stuttgart, E. Schweizerbart'sche Verlagsbuchhandlung, p. 60-75.

Heller, J., 1993, Hermaphroditism in molluscs: Biological Journal of the Linnean Society, v. 48, p. 19-42.

Hethke, M., Fürsich, F.T., Morton, J.D., and Jiang, B., 2018, Analysis of morphological variability in the clam shrimp Eosestheria middendorfii (Crustacea, Spinicaudata) from the Lower Cretaceous of China, and its implications for spinicaudatan taxonomy: Papers in Palaeontology, v. 4, p. 21-53.

Hoagland, K.E., 1984, Use of the terms protandry, protogyny, and hermaphroditism in malacology: American Malacological Bulletin, v. 3, p. 85-88

Jablonski, D., and Lutz, R.A., 1980, Molluscan larval shell morphology, in Rhoads, D.C., and Lutz, R.A., eds., Skeletal Growth of Aquatic Organisms: New York, Plenum Press, p. 323-377.

Jenner, C.E., and McCrary, A.B., 1968, Sexual dimorphism in erycinacean bivalves: American Malacological Union, Annual Report, v. 35, p. 43.

Karapunar, B., Werner, W., Fürsich, F.T., and Nützel, A., 2020, Taxonomy and palaeoecology of the Early Jurassic (Pliensbachian) bivalves from Buttenheim, Franconia (Southern Germany): Palaeontographica Abteilung A, v. 318, p. $1-127$.

Kauffman, E.G., and Buddenhagen, C.H., 1969, Protandric sexual dimorphism in Paleocene Astarte [Bivalvia] of Maryland, in Westermann, G.E.G., ed., Sexual Dimorphism in Fossil Metazoa and Taxonomic Implications: Stuttgart, E. Schweizerbart'sche Verlagsbuchhandlung, p. 76-93.

Koppka, J., and Malchus, N., 2007, Early ontogeny and micro-ornamentation of Nicaniella and Pressastarte (Bivalvia: Astartinae) from the Jurassic of the Southern Baltic, in Jordaens, K., Van Houtte, N., Van Goethem, J., and Backeljau, T., eds., World Congress of Malacology, Antwerp, Belgium, 15-20 July 2007 Abstracts: Antwerp, University of Antwerp, p. $119-120$.

Kotrla, M.B., and James, F.C., 1987, Sexual dimorphism of shell shape and growth of Villosa villosa (Wright) and Elliptio icterina (Conrad) (Bivalvia: Unionidae): Journal of Molluscan Studies, v. 53, p. 13-23.

Kuhn, O., 1935, Die Fauna des untersten Lias delta (Gibbosus-Zone) aus dem Sendelbach im Hauptsmoorwald östlich Bamberg: Neues Jahrbuch für Mineralogie, Geologie und Paläontologie B, Beilage-Band, no. 73, p. $465-493$.

Lea, I., 1831, Observations on the naïades, and descriptions of new species of that and other families: Transactions of the American Philosophical Society, n. ser., v. 4, p. $63-121$

Lea, I., 1834, Observations on the naïades, and descriptions of new species of that and other families: Transactions of the American Philosophical Society, n. ser., v. 5, p. 23-119.

Linnaeus, C., 1758, Systema Naturae: per regna tria naturae, secundum classes, ordines, genera, species, cum characteribus, differentiis, synonymis, locis, ed. 10: Holmiae [Stockholm], Laurentius Salvius, v. 1, 824 p.

Mackie, G.L., 1984, Bivalves, in Tompa, A.S., Verdonk, N.H., and Van Den Biggelaar, J.A.M., eds., The Mollusca, Vol. 7. Reproduction: New York, Academic Press, p. 351-418.

Merrill, A.S., and Burch, J.B., 1960, Hermaphroditism in the sea scallop, Placopecten magellanicus (Gmelin): Biological Bulletin, v. 119, p. 197-201.

Morton, B., 1980, Some aspects of the biology and functional morphology (including the presence of a ligamental lithodesma) of Montacutona compacta and M. olivacea (Bivalvia: Leptonacea) associated with coelenterates in Hong Kong: Journal of Zoology, v. 192, p. 431-455.

Ostroumoff, A., 1900, Note sur le dimorphism sexuel chez le genere Astarte Sow.: Zoologischer Anzeiger, v. 23, p. 499-500.

Pascual, M.S., Iribarne, O.O., Zampatti, E.A., and Bocca, A.H., 1989, Femalemale interaction in the breeding system of the puelche oyster Ostrea puelchana d'Orbigny: Journal of Experimental Marine Biology and Ecology, v. 132 , p. 209-219.

Pérez, D.E., and Soto, I.M., 2021, The incubatory chamber of marsupial carditids (Bivalvia: Carditidae: Thecaliinae) as an exaptation: Paleobiology, p. 114. https://doi.org/10.1017/pab.2021.10.

Pérez, D.E., Alvarez, M.J., and del Río, C.J., 2017, Un posible caso de dimorfismo sexual en "Venericardia" patagonica (Sowerby, 1846) (Bivalvia: Carditidae): Revista Brasileira de Paleontologia, v. 20, p. 195-202.

Philippi, R.A., 1887, Los Fósiles Terciarios i Cuaternarios de Chile: Leipzig, Brockhaus, $256 \mathrm{p}$.

Policansky, D., 1982, Sex change in plants and animals: Annual Review of Ecology and Systematics, v. 13, p. 471-495. 
Ponder, W.F., Lindberg, D.R., and Ponder, J.M., 2020, Biology and Evolution of the Mollusca. Vol. 1: Boca Raton, CRC Press, 924 p.

Rohlf, F.J., 2017, tpsDig, digitize landmarks and outlines, v. 2.31. Department of Ecology \& Evolution, State University of New York at Stony Brook: https://life.bio.sunysb.edu/morph/soft-dataacq.html.

Ros-Franch, S., Márquez-Aliaga, A., and Damborenea, S.E., 2014, Comprehensive database on Induan (Lower Triassic) to Sinemurian (Lower Jurassic) marine bivalve genera and their paleobiogeographic record: Paleontological Contributions, no. 8, p. 1-219.

Saleuddin, A., 1964, The gonads and reproductive cycle of Astarte sulcata (da Costa) and sexuality in A. elliptica (Brown): Journal of Molluscan Studies, v. 36, p. $141-148$

Saleuddin, A., 1965, The mode of life and functional anatomy of Astarte spp. (Eulamellibranchia): Journal of Molluscan Studies, v. 36, p. 229-257.

Sastry, A., 1979, Pelecypoda (excluding Ostreidae), in Giese, A., and Pearse, J., eds., Reproduction of Marine Invertebrates, Volume V, Molluscs: Pelecypods and Lesser Classes: New York, Academic Press, p. 113-292.

Schneider, S., Fürsich, F.T., Schulz-Mirbach, T., and Werner, W., 2010, Ecophenotypic plasticity versus evolutionary trends in Upper Jurassic bivalve shells from Portugal: Acta Palaeontologica Polonica, v. 55, p. 701-732.

Schneider, S., Fürsich, F.T., and Werner, W., 2011, Biometric methods for species recognition in Trigonia Bruguière (Bivalvia; Trigoniidae): a case study from the Upper Jurassic of Western Europe: Paläontologische Zeitschrift, v. 85 , p. $257-267$

Shipway, J., O'Connor, R., Stein, D., Cragg, S., Korshunova, T., Martynov, A., Haga, T., and Distel, D., 2016, Zachsia zenkewitschi (Teredinidae), a rare and unusual seagrass boring bivalve revisited and redescribed: PloS one, v. 11, no. 5, e0155269. https://doi.org/10.1371/journal.pone.0155269.

Sowerby, G.B., 1846, Description of the Tertiary fossils shells from South America, in Darwin, C., ed., Geological Observations on the Volcanic Islands and Parts of South America Visited During the Voyage of H.M.S. "Beagle": London, D. Appleton and Company, p. 249-264.

Spärck, R., 1927, Is the crenulated shell-border of Astarte sulcata due to sexual dimorphism?: Videnskabelige Meddelelser fra Dansk naturhistorisk Forenig i København, v. 84, p. 291-292.

Stanley, S.M., 1988, Adaptive morphology of the shell in bivalves and gastropods: The Mollusca, v. 11, p. 105-141.

Taki, I., and Habe, T., 1950, Xylophaginidae in Japan: Illustrated Catalogue of Japanese Shells, v. 1, no. 7, p. 45-47.

Turner, R.D., and Yakovlev, Y., 1983, Dwarf males in the teredinidae (Bivalvia, Pholadacea): Science, v. 219, p. 1077-1078

Vermeij, G.J., 2002. Characters in context: molluscan shells and the forces that mold them: Paleobiology, v. 28, p. 41-54.

Vermeij, G.J., 2013, Molluscan marginalia: hidden morphological diversity at the bivalve shell edge: Journal of Molluscan Studies, v. 79, p. 283-295.

Zieritz, A., and Aldridge, D.C., 2011, Sexual, habitat-constrained and parasite-induced dimorphism in the shell of a freshwater mussel (Anodonta anatina, Unionidae): Journal of Morphology, v. 272, p. 1365-1375. 